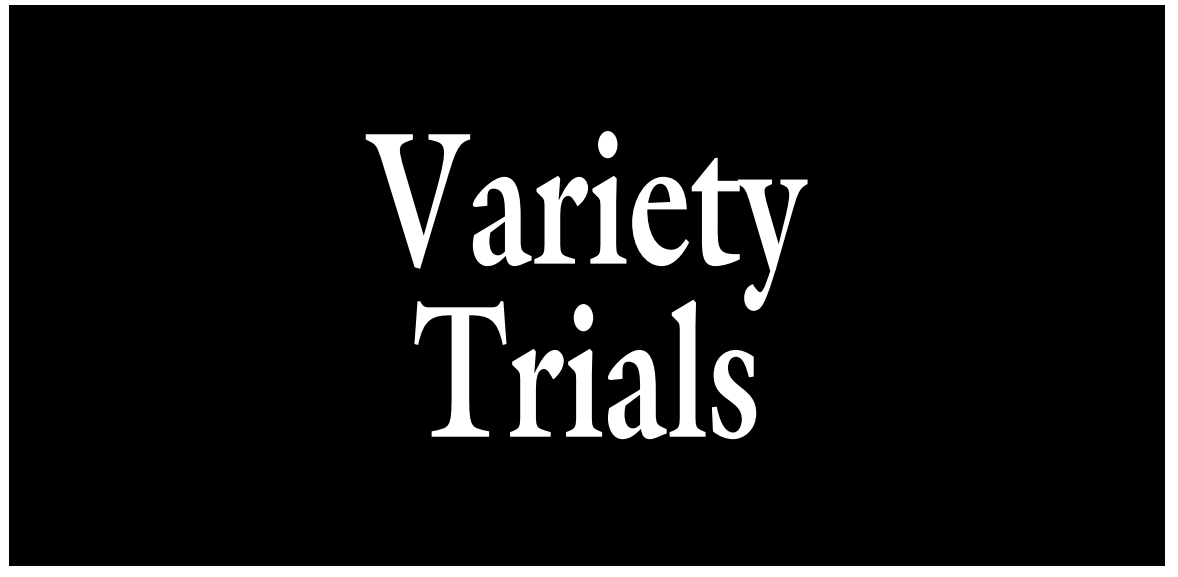

\title{
Fruit Quality and Consumer Acceptability of Three Plum Types and 14 Plum Cultivars Grown in Maine for a Local Market
}

\author{
Angela D. Myracle, Zakkary J. Castonguay, Amber Elwell, and \\ Renae E. Moran ${ }^{1}$
}

AdDitional Index wORDs. Prunus salicina, Prunus domestica, Prunus americana, postharvest, soluble solids, titratable acidity, texture, sensory evaluation

SUMMARY. Fruit quality and consumer acceptance were measured in 14 plum cultivars. In 2015, six cultivars of asian plum (Prunus salicina) and one cultivar of american plum (Prunus americana) were harvested partially ripe and tree-ripe. In 2016, three types of plums, asian, american, and european (Prunus domestica), were harvested tree-ripe. Within most cultivars in 2015 , partially ripe fruit were rated as highly as tree-ripe fruit using a hedonic rating from 1 to 9 with 1 being dislike extremely and 9 being like extremely. 'Obilnya' and 'Abundance' were rated higher than 'Shiro' and 'Methley' at both stages of ripeness and higher than 'Vanier' at the partially ripe stage. 'Early Golden' and 'Spring Satin' were rated higher than 'Shiro' and 'Methley' at the tree-ripe stage. In 2016, seven cultivars (Obilnya, Kahinta, Superior, Toka, Castleton, Early Italian, and Rosy Gage) were scored at the desired consumer acceptance level. 'Shiro' and 'Caçak's Best' received overall acceptability scores below the level of acceptability. Plum type had minimal effect on scores for texture, sweetness, sourness, and overall liking. European cultivars received lower color scores than american and asian plums. Soluble solids concentration (SSC) ranged from $6.7 \%$ to $13.6 \%$ in asian plums, from $14.8 \%$ to $19.8 \%$ in american plums, and from $15.3 \%$ to $22.1 \%$ in european plums. Overall consumer acceptance of american and european cultivars was as good as for asian cultivars.

A

nnual consumption of fresh plums in the United States is $0.6 \mathrm{lb}$ per capita, which is lower than that of similar types of fruit such as sweet cherry (Prunus avium) and peach (Prunus persica) that have an annual per capita consumption of 1.1 and $2.8 \mathrm{lb}$, respectively (U.S. Department of Agriculture, 2017). Low consumption may be due to the lower quality that occurs with harvest at an early stage of fruit maturity, a necessary practice to prevent bruising and premature ripening during long-distance shipping. Producers harvest plums when flesh firmness reaches $10 \mathrm{lbf}$, but plums are not considered ready to eat until they soften to 2-3 lbf (Crisosto, 1994; Kader and Mitchell, 1989; Robertson et al., 1992). Harvesting plums at more advanced stages of maturity can improve fruit quality and consumer acceptance but leads to a reduction in shelf life and greater potential for damage during shipping and distribution (Abdi et al., 1997; Candan et al., 2008; Crisosto et al., 2004; Fajt and Usenik, 2010). By growing plums closer to their intended market, they can be marketed without the need for long-distance shipping, which allows growers to harvest them at a later stage of maturity when quality is optimal.

To create cultivars with improved fruit quality, the asian plum has been hybridized with the apricot plum (Prunus simonii), the myrobalan plum (Prunus ceracifera), and other species and for cold temperature tolerance, it has been hybridized with american and canadian plum (Prunus nigra) (Hansen, 1915; Okie and Ramming, 1999). This has resulted in interspecific plums derived from the asian plum that are referred to as asian or japanese plums, and american plum (Table 1). European plums with sufficient cold temperature tolerance can be an option in zones 4 and 5 but differ in texture, flavor, and appearance from asian and american plums and are relatively unknown to most consumers. The asian plums 'Shiro' and 'Methley' are grown for their consistently high yield in cold regions but knowledge on the consumer acceptance of these and other cold hardy plums needs further evaluation. Cultivation of plums in eastern and northern growing regions of the United States and Canada requires cultivars that possess cold temperature tolerance, resistance to bacterial leaf spot, and rain cracking resistance (Norton et al., 1987), but these traits are not typically present in asian cultivars selected for longdistance shipping.

Consumer preference depends on flavor, texture, and appearance, which vary with cultivar and maturity at

\begin{tabular}{llll}
\hline $\begin{array}{l}\text { Units } \\
\text { To convert U.S. to SI, } \\
\text { multiply by }\end{array}$ & U.S. unit & SI unit & $\begin{array}{l}\text { To convert SI to U.S., } \\
\text { multiply by }\end{array}$ \\
\hline 29.5735 & $\mathrm{fl} \mathrm{oz}$ & $\mathrm{mL}$ & 0.0338 \\
2.54 & inch $(\mathrm{es})$ & $\mathrm{cm}$ & 0.3937 \\
0.4536 & $\mathrm{lb}$ & $\mathrm{kg}$ & 2.2046 \\
4.4482 & $\mathrm{lbf}$ & $\mathrm{N}$ & 0.2248 \\
1.6093 & $\mathrm{mile}(\mathrm{s})$ & $\mathrm{km}$ & 0.6214 \\
28.3495 & $\mathrm{Oz}$ & $\mathrm{g}$ & 0.0353 \\
$\left({ }^{\circ} \mathrm{F}-32\right) \div 1.8$ & ${ }^{\circ} \mathrm{F}$ & ${ }^{\circ} \mathrm{C}$ & $\left({ }^{\circ} \mathrm{C} \times 1.8\right)+32$
\end{tabular}


harvest (Boyhan et al., 1996; Corollaro et al., 2014; Crisosto et al., 2003). These traits can be measured with sensory testing using the untrained general public and a hedonic liking scale from 1.0 to 9.0 (Peryam and Pilgrim, 1957). For plums sold in supermarkets, a hedonic degree of liking score greater than 5.0 (neither like nor dislike) is considered consumer accepted (Crisosto et al., 2004). However, minimum acceptability scores as low as 5.0 could potentially lead to cultivar recommendations that have only slightly positive ratings of liking (Meredith et al., 1992). To ensure successful marketing, food products are expected to score at least 7.0 (Stone et al., 2012).

Soluble solids concentration, titratable acidity (TA), and flesh firmness are commonly used as indirect measures of fruit quality. Consumer acceptance of plums tends to be more favorable as SSC increases from below $10 \%$ to above $14 \%$, but TA becomes important when SSC is below $12 \%$ (Crisosto et al., 2004). Most of the commercially important cultivars emit low amounts of aroma volatiles (Gómez and Ledbetter, 1994), so sweetness and sourness contribute most to plum flavor (Singh and Singh, 2008) and consumer acceptance (Crisosto et al., 2003). However, these traits are not as well characterized in american plums. Texture is not well studied in plums but has an impact on acceptability of sweet cherry (Chauvin et al., 2009), peach (Olmstead et al., 2015), and northern highbush blueberry [Vaccinium corymbosum (Gilbert et al., 2014)]. Many factors in addition to sweetness, sourness, and firmness contribute to fruit quality such as aroma, bitterness, astringency, and juiciness for which optimum ranges are not yet established. Because of the

This research was funded in part by the Maine Department of Agriculture, Conservation and Forestry, and by the United States Department of Agriculture Federal Formula Hatch Funds under project NE1336.

We acknowledge the valuable assistance of Xue Du, Bouhee Zeng, Katherine Davis-Dentici, and Mary Ellen Camire. Maine Ag. and Forest Expt. Stn. no. 3591 .

Mention of a trademark, proprietary product, or vendor does not constitute a guarantee or warranty of the product and does not imply its approval to the exclusion of other products that may also be suitable.

School of Food and Agriculture, University of Maine, Rogers Hall, Orono, ME 04469

${ }^{1}$ Corresponding author. E-mail: rmoran@maine.edu. https://doi.org/10.21273/HORTTECH03958-18 complex nature of quality, consumer testing is needed to identify cultivars with high consumer appeal. The objectives of this research were to determine if the partially ripe stage of maturity is as acceptable as the tree-ripe stage of maturity in several asian plum cultivars and to determine the consumer acceptability of three plum types that possess cold hardiness in U.S. Department of Agriculture hardiness zone 5.

\section{Materials and methods}

Fruit were acquired from several sources for consumer testing. Most cultivars were grown at the University of Maine Highmoor Farm in Monmouth, ME (lat. $44^{\circ} 14^{\prime} \mathrm{N}$, long. $\left.70^{\circ} 3^{\prime} \mathrm{W}\right)$, where trees were planted as three randomized complete block designs. Two trees each of 'Toka', 'Kahinta', and 'Superior' were planted in 2006. Five trees each of 'Early Golden', 'Shiro', 'Methley', 'Spring Satin', and 'Vanier' were planted in 2007. Three trees each of 'Obilnya', 'Rosy Gage', 'Castleton', and 'Caçak's Best' were planted in 2008. Each of these plantings was located in separate locations on the same farm. On 9 Aug. 2015, 'Abundance' was harvested from a commercial farm in Fairfield, ME, located 36 miles north of the Highmoor Farm. 'Early Italian' was purchased from a supermarket on 16 Aug. 2016 and was grown at an unknown location. All trees were trained and pruned according to the open-center system. Trees were grown according to New England commercial production practices (Cooley et al., 2015). All trees were hand-thinned to a uniform crop load in mid-June.

EXPERIMENT 1. During early Aug. to mid Sept. 2015, 20-50 fruit were harvested from two to five trees of each cultivar for a total of 100 fruit per cultivar except Toka where only 40 fruit were harvested because of limited supply. The first consumer testing was held on 4-5 Aug. with 'Spring Satin', 'Methley', and 'Early Golden', the second testing on 10-11 Aug. with 'Obilnya' and 'Shiro', and the third testing on 3-4 Sept. with 'Vanier' and 'Abundance'. 'Spring Satin' plumcot was included because of its strong resemblance to plums. Sufficient numbers of 'Toka' fruit were available for inclusion in fruit quality measurements but not for consumer testing. Harvested fruit were selected at two stages of maturity on the same day, tree-ripe and partially ripe, according to skin color and firmness changes specific to each cultivar. Because of the large variation in maturity of fruit on the same tree, firmness was assessed by gently handsqueezing fruit to determine which fruit were sufficiently ripe to harvest. Peel color was also visually assessed to select fruit for harvest. 'Spring Satin' was assessed at only the tree-ripe stage because of the disparity in ripening among the three cultivars selected for the first consumer testing date.

EXPERIMENT 2. During early Aug. to mid Oct. 2016, 20-50 fruit were harvested from two to five trees of each cultivar for a total of 100 fruit per cultivar. An exception was 'Early Italian' which was purchased from a supermarket the same day as consumer testing as a measure of a locally available commercially grown european cultivar. The first consumer testing was held on 16 Aug. with 'Shiro', 'Obilnya', and 'Early Italian'. The second testing was held on 9 Sept. when 'Rosy Gage', 'Castleton', and 'Superior' were tested. The third testing was held on 15 Sept. when 'Kahinta', 'Toka', and 'Caçak's Best' were tested. Harvested fruit were selected at the tree-ripe stage of maturity. Insufficient fruit were available to consumer test 'Spring Satin', 'Early Golden', 'Methley', and 'Vanier', and for fruit quality measurement of 'Spring Satin' and 'Vanier'.

Consumer testing. Consumer testing was conducted $1-3 \mathrm{~d}$ after harvest with fruit that had been held at room temperature except 'Spring Satin', 'Shiro', and 'Methley' in Expt. 1 , which were cold-stored for $2 \mathrm{~d}$ at $1^{\circ} \mathrm{C}$. The consumer testing was held at the University of Maine Sensory Evaluation Center. This testing was approved by the University of Maine Institutional Review Board for the Protection of Human Subjects and participants were compensated four dollars for their time. Participants were recruited at the University of Maine via fliers posted around campus and announcements through an e-mail list maintained by the university. Because of the variation in harvest dates of the plum cultivars, testing was conducted in three different sessions. Each session was completed over a 2 -d period or until there 
Table 1. Plum and plum hybrid cultivars evaluated in this study and their respective type and species.

\begin{tabular}{lllll}
\hline Cultivar & \multicolumn{1}{c}{ Type } & \multicolumn{1}{c}{ Species } & Skin color & Flesh color \\
\hline Abundance & Asian & Prunus salicina & Red & Yellow \\
Caçak's Best & European & Prunus domestica & Purple & Gold \\
Castleton & European & P. domestica & Purple & Gold \\
Early Golden & Asian & P. salicina hybrid & Yellow & Yellow \\
Early Italian & European & P. domestica & Purple & Gold \\
Kahinta & American & P. salicina $\times$ Prunus americana & Red & Gold \\
Methley & Asian & P. salicina $\times$ Prunus ceracifera & Purple & Red \\
Obilnya & Asian & P. salicina $\times$ P. ceracifera & Purple & Orange \\
Rosy Gage & European & P. domestica & Pink/green & Green \\
Shiro & Asian & P. salicina $\times$ Prunus simonii $) \times$ & Yellow & Yellow \\
& & $\quad$ P. cerasifera $\times$ Prunus & & \\
Spring Satin & Plumcot & P. salicina $\times$ Prunus armeniaca & Purple & Yellow \\
Superior & American & P. salicina $\times($ P. americana $\times$ & Red & Gold \\
& & P. simonii $)$ & & \\
Toka & American & P. americana $\times$ P. simonii & Dark red & Gold \\
Vanier & Asian & P. salicina $\times$ P. simonii & Red & Yellow \\
\hline
\end{tabular}

z'Abundance' plums were grown in a commercial orchard in Fairfield, ME.

'Early Italian' plums were purchased from a local supermarket. Location of production was unknown.

were 100 participants. During the second testing date in Expt. 1, there were only 84 participants since it coincided with the 2 weeks before start of fall semester, a time when most faculty and staff were absent. The sensory testing ballot was created and executed using SIMS 2000 software (Sensory Computer Systems, Morristown, NJ).

Plum samples were prepared in a negative pressure kitchen and distributed to participants through a small sliding window to their individual stations. The participants were seated at a partitioned desk with lighting to emulate "Northern Daylight 65." Samples were assigned a three-digit randomized code assigned by SIMS. The plums were cut into quarters or sixths, depending on the size of the plum, with the pit removed but the skin attached. Panelists were not otherwise involved in the study and were not informed of which cultivars were under evaluation. For each cultivar and stage of maturity, two vertical slices of fruit with the peel and that were free of blemishes were placed in white ceramic dishes labeled with the assigned three-digit randomized code. Participants were also given water, napkin, and a laminated sheet with plum images printed to-scale to assist in answering the sizing preference question.

The same testing ballot was used for all tests and consisted of demographic, hedonic, and Likert scale questions. Demographic and frequency questions were presented before sampling and were followed by five hedonic questions about color, sweetness, skin tartness, texture, and overall liking, with $1=$ dislike extremely and $9=$ like extremely (Peryam and Pilgrim, 1957). Open-ended comments were optional for each of the samples, allowing for additional comments and comparisons to be made. The hedonic questions were repeated for each sample and presented in the same order. After sampling was complete, participants answered a follow-up set of questions, which included a seven-point Likert scale $(1=$ strongly agree and $7=$ strongly disagree), which was used to assess likelihood of purchasing and fruit size preference. Size preference was assessed using a tangible, to-scale picture reference of plums at three sizes, $1.0,1.5$, and 2 inches in diameter, which represent the size of plums grown in Maine.

Fruit Quality analysis. Flesh firmness was measured the same day as harvest on 5-10 fruit of each cultivar and stage of maturity with a hand-held Effigi-type penetrometer and an 8 -mm tip (Fruit Hardness Tester model 803; General Specialty Tools and Instruments, Secaucus, NJ). Pressure testing was performed on two sides of the plums not next to the seam and after removing a section of the peel.

Soluble solids concentration, $\mathrm{pH}$, and $\mathrm{TA}$ were measured using filtered juice from a pooled sample of 5-10 fruit. The samples were prepared by blending pitted plums for $5 \mathrm{~s}$ in a centrifuge $5804 \mathrm{R}$; Eppendorf, Hamburg, Germany) for $10 \mathrm{~min}$ at $3234 g_{n}$. The centrifuged samples were filtered through Whatman \#4 filter paper (GE Healthcare Lifesciences, Chicago, IL) in a Buchner funnel with an applied vacuum. The samples were stored at $-20{ }^{\circ} \mathrm{C}$ until analysis. Soluble solids concentration was measured in triplicate with a digital refractometer (model PAL-3; Atago, Bellevue, WA). Titratable acidity was measured using an automated titrator (HI 84532; Hanna Instruments, Carrollton, TX) on all samples. Titratable acidity was measured in duplicate in 2015 as long as the values were within $\pm 0.05 \%$ of one another and in triplicate in 2016. In a subset of samples in 2015, a manual burette titration was used to ensure accuracy of the automatic fruit juice titration values. Both methods showed similar accuracy. Titratable acidity was measured by both means using $5 \mathrm{~mL}$ of the prepared juice sample and $45 \mathrm{~mL}$ of ultrapure water. The manual burette method used standard 0.1 normal sodium hydroxide $(\mathrm{NaOH})$ to bring the $\mathrm{pH}$ to 8.1. Titratable acidity was represented as percent malic acid (MA) as this is the predominant acid found in plums (Bae et al., 2014). Percent MA was calculated using the following equation:

percent acid $=$

$\frac{(\text { milliliters } \mathrm{NaOH}) \times(0.1 \mathrm{NaOH}) \times(0.067) \times(100)}{\text { grams of sample }}$

Fruit quality and consumer testing data collected in 2015 were analyzed for the main effect of type, cultivar, and stage of maturity as well as their interaction using the general linear models procedure of SAS (version 9.1; SAS Institute, Inc., Cary, NC) and Tukey's honestly significant difference test for means separation. Data collected in 2016 were analyzed using the same method but for only the main effects of cultivar and type. Because type was confounded with cultivar, the interaction of these two effects could not be analyzed.

\section{Results}

CONSUMER DEMOGRAPHICS. In both experiments, most of the participants were female and the largest age 
group represented was $18-24$ years (Table 2). Most of the participants consumed plums infrequently, one to four times per year. Responses regarding preference for fruit size indicated that larger plums were preferred. Most of the participants also indicated that the health benefits of food were important when making food choices.

Consumer testing. In Expt. 1, hedonic scores were generally lower for most traits in 'Shiro' and 'Methley' than for other cultivars (Fig. 1). In most cultivars, consumers preferred partially ripe fruit as much as tree-ripe. However, the stage of maturity affected consumer acceptance in 'Early Golden' and 'Vanier', in which tree-ripe were preferred over partially ripe fruit.

Hedonic scores for color varied among cultivars $(P<0.01)$ and stage of maturity $(P<0.01)$ with a significant interaction $(P<0.01)$. The effect of maturity was cultivar dependent. 'Early Golden' harvested tree-ripe received a higher color score than when harvested partially ripe. However, for other cultivars, color scores did not vary among partially ripe and tree-ripe. Among partially ripe fruit, 'Obilnya' received the highest score for color, which was greater than for 'Abundance', 'Early Golden', 'Shiro', and 'Vanier'. 'Shiro' received lower color scores than other cultivars except Early
Golden. Among tree-ripe fruit, color scores were not as variable among cultivars. 'Early Golden', 'Methley', and 'Obilnya' received the highest color scores, followed by 'Abundance', 'Spring Satin', and 'Vanier'. 'Shiro' had the lowest color score among tree-ripe fruit.

Hedonic scores for texture varied among cultivars $(P<0.01)$, but for most cultivars, there was no difference between the two stages of maturity $(P=0.92)$. However, the interaction between cultivar and maturity was significant $(P=0.04)$. For 'Methley', tree-ripe fruit received lower scores than partially ripe fruit. Among partially ripe fruit, 'Obilnya' received the highest texture score, followed by 'Abundance' and 'Early Golden'. Scores for 'Methley', 'Shiro', and 'Vanier' were lower than for 'Obilnya' and 'Abundance' but were similar to 'Early Golden'. In tree-ripe fruit, 'Abundance', 'Early Golden', 'Obilnya', 'Spring Satin', and 'Vanier' received higher scores than 'Methley', whereas 'Shiro' received intermediate scores that were similar to 'Vanier' and 'Methley'.

Hedonic scores for sweetness varied with cultivar $(P<0.01)$ and stage of maturity $(P<0.01)$ with a significant interaction $(P<0.01)$. The effect of maturity was cultivar dependent. Tree-ripe fruit of 'Early
Golden' and 'Vanier' received higher scores for sweetness than partially ripe fruit. For other cultivars, there was no difference between partially ripe and tree-ripe fruit. Among partially ripe fruit, 'Abundance' and 'Obilnya' received higher sweetness scores than other cultivars. Among tree-ripe fruit, 'Early Golden', 'Obilnya', and 'Spring Satin' received higher scores than 'Methley' and 'Shiro' but similar scores to 'Abundance', which was also similarly scored as 'Methley' and 'Shiro'.

Hedonic scores for skin tartness varied with cultivar $(P<0.01)$ and stage of maturity $(P<0.01)$ with a significant interaction $(P<0.01)$. The effect of maturity was cultivar dependent. Scores were similar for the two stages of maturity in most cultivars, but in Early Golden and Vanier, tree-ripe fruit scored higher than partially ripe fruit. Among partially ripe fruit, 'Abundance' and 'Obilnya' scored higher than other cultivars. Among tree-ripe fruit, 'Methley' and 'Shiro' scored lower than other cultivars.

Hedonic scores for overall acceptability varied with cultivar $(P<$ $0.01)$ and stage of maturity $(P<0.01)$ with no interaction $(P=0.08)$. The effect of maturity not was cultivar dependent. Tree-ripe fruit received higher scores than partially ripe fruit.

Table 2. Demographic characterization of the three-session consumer panels for plum cultivar evaluation in $2015(n=100$, 84 , and 100 for each of the three sessions, respectively) and $2016(n=98,100$, and 100).

\begin{tabular}{|c|c|c|c|}
\hline \multirow[b]{2}{*}{ Variable } & \multirow[b]{2}{*}{ Response category } & \multicolumn{2}{|c|}{ Proportion of total (\%) } \\
\hline & & 2015 & 2016 \\
\hline \multirow[t]{2}{*}{ Gender } & Male & 39.6 & 38.6 \\
\hline & Prefer not to say & 0.4 & 0.0 \\
\hline \multirow[t]{2}{*}{ Age in years } & $18-24$ & 44.6 & 45.0 \\
\hline & $25-38$ & 30.9 & 35.2 \\
\hline \multirow[t]{5}{*}{ Frequency of plum consumption } & Never & 7.4 & 6.7 \\
\hline & $1-4$ times per year & 54.4 & 56.4 \\
\hline & $1-2$ times per month & 31.2 & 25.8 \\
\hline & 1-2 times per week & 6.3 & 9.7 \\
\hline & 3 or more times per week & 0.7 & 1.6 \\
\hline of foods before I choose to eat them.” & Agree somewhat & 45.9 & 50.9 \\
\hline & Neither likely or unlikely & 3.9 & 2.3 \\
\hline & Somewhat unlikely & 3.5 & 2.6 \\
\hline & Very unlikely & 0.7 & 0.6 \\
\hline
\end{tabular}

${ }^{\mathrm{z}} 1$ inch $=2.54 \mathrm{~cm}$. 




Fig. 1. Hedonic acceptability rating of color, texture, sweetness, sourness, and overall liking in one plum-apricot cultivar (Spring Satin) and six asian plum cultivars harvested at two stages of fruit maturity, partially ripe and tree-ripe, in 2015; $1=$ dislike extremely and $9=$ like extremely. Bars with the same letters are not statistically significant at $P \leq 0.05$ by Tukey's honestly significant difference; * indicates a significant difference between stage of maturity within a cultivar.

Among partially ripe fruit, 'Abundance and 'Obilnya' received the highest scores, 'Early Golden' an intermediate score, and 'Methley', Shiro', and 'Vanier' the lowest. Among tree-ripe fruit, 'Methley' and 'Shiro' scored lower than other cultivars.

In Expt. 2, the cultivar had a larger effect on hedonic scores than plum type for most traits (Fig. 2). However, plum type affected preference
Hedonic scores for texture varied among cultivars, but did not differ greatly among asian, american, and european plums. 'Kahinta', which received the highest texture scores, was rated as highly as all cultivars except Shiro, which received the lowest rating. Texture ratings of 'Superior', 'Toka', and 'Caçak's Best' were not significantly different from that of 'Shiro'.

Scores for sweetness varied among cultivars and not among plum types. Scores were lower for 'Shiro' and 'Caçak's Best' than for other cultivars.

Hedonic scores for tartness were variable among cultivars but did not differ among types. 'Obilnya' had the highest hedonic score for tartness, followed by 'Kahinta', 'Superior', 'Toka', 'Early Italian', and 'Rosy Gage'. Scores for 'Shiro' and 'Caçak's Best' were lower than that for other cultivars except for Castleton, which scored similarly as Caçak's Best.

Scores for overall liking varied with the cultivar and the type of plum. Among cultivars, Caçak's Best and Shiro received lower scores than other cultivars. American plums generally scored higher than european and asian plums for overall liking with some exceptions such as the asian cultivar Obilnya, which scored as highly as all the american cultivars.

Fruit QUALITY INDICATORS. In Expt. 1, flesh firmness varied primarily with cultivar and with stage of maturity with no interaction (Table 3). Firmness was greater in partially ripe fruit than in tree-ripe. When harvested partially ripe, 'Obilnya' and 'Vanier' had the firmest fruit and 'Methley' had the least firm. In treeripe fruit, 'Obilnya', 'Spring Satin', and 'Vanier' had the greatest firmness, followed by 'Abundance', 'Early Golden', 'Methley', and 'Shiro' which had the lowest firmness.

Soluble solids concentration varied with cultivar and stage of maturity with a significant interaction. In 'Early Golden', 'Obilnya', 'Abundance', 'Vanier', and 'Toka', SSC was higher in tree-ripe fruit compared with partially ripe fruit. In contrast, 'Methley' and 'Shiro' had higher SSC in partially ripe fruit compared with tree-ripe. Among partially ripe fruit, 'Toka' had the highest SSC, followed by 'Methley' and 'Obilnya'. 'Vanier' and 'Abundance' were intermediate 


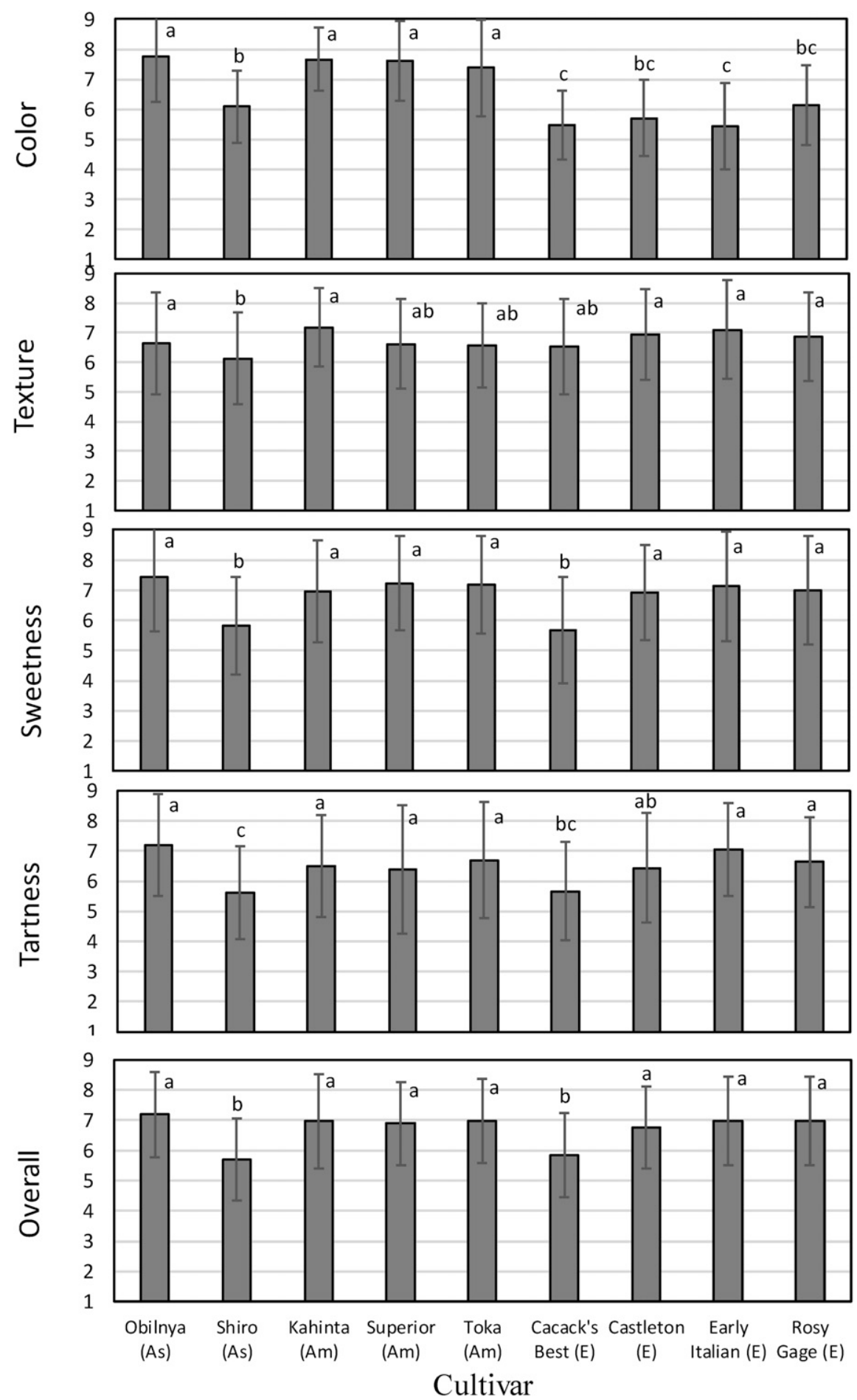

Fig. 2. Hedonic acceptability rating of color, texture, sweetness, sourness, and overall liking in asian (As), american (Am), and european (E) plum cultivars harvested tree-ripe in 2016; $1=$ dislike extremely and $9=$ like extremely. Bars with the same letters are not statistically significant at $P \leq 0.05$ by Tukey's honestly significant difference.

in SSC and 'Early Golden' and 'Shiro' were lowest. Among tree-ripe fruit, SSC was greatest in 'Toka' and 'Spring Satin'; intermediate in 'Methley', 'Obilnya', and 'Vanier'; and lowest in 'Abundance', 'Early Golden', and 'Shiro'.
Among partially ripe fruit, 'Early Golden' and 'Obilnya' had greater MA than other cultivars. 'Methley' and 'Vanier' had lower MA than other cultivars harvested partially ripe. 'Early Golden' and 'Obilnya' had the greatest MA in tree-ripe fruit, followed by 'Shiro' and 'Toka'. Malic acid was lowest in 'Abundance', 'Methley', and 'Vanier', and intermediate in 'Spring Satin'.

In most cultivars, the ratio of SSC to MA was greater in tree-ripe than in partially ripe fruit. However, in 'Methley', both stages had similar ratios and in 'Shiro', the ratio was lower in tree-ripe than in partially ripe fruit. In partially ripe fruit, SSC:MA was greatest in 'Vanier' and 'Toka' and was lowest in 'Early Golden'. In tree-ripe fruit, 'Spring Satin' had the greatest SSC:MA and 'Early Golden' had the lowest.

In Expt. 2, flesh firmness varied among cultivars and among plum types (Table 4). Firmness was greatest in 'Superior' and 'Castleton', intermediate in 'Kahinta' and 'Rosy Gage', and lowest in 'Obilnya', 'Shiro', and 'Toka'. Asian cultivars had lower firmness than american and european cultivars. Firmness was not measured in all cultivars because of the limited number of fruit available.

Soluble solids concentration varied with the cultivar and with the plum type. European cultivars had higher SSC compared with asian and most american cultivars, but the american plum Toka had SSC that was as high as in most european cultivars. The other american plums, 'Kahinta' and 'Superior', had SSC that was intermediate to european and asian cultivars. 'Early Italian' had the highest SSC and 'Shiro' the lowest.

Malic acid varied among cultivars and plum types. 'Superior' had similar MA as 'Early Golden' and 'Kahinta', but greater than that in other cultivars. 'Obilnya', 'Early Italian', 'Rosy Gage', and 'Toka' had intermediate MA. 'Methley', 'Shiro', 'Caçak's Best', and 'Castleton' had the lowest MA. American plums had greater MA than european plums, and asian plums were intermediate to the other two types, but this was not consistent for every cultivar within a type. 'Toka', an american plum, had lower MA than some asian and european cultivars. 
Table 3. Fruit quality attributes of one plum-apricot (P-A), one american (Am), and six asian (As) plum cultivars harvested at two stages of maturity, partially ripe (PR) and tree-ripe (TR), in 2015.

\begin{tabular}{|c|c|c|c|c|c|c|c|c|c|}
\hline \multirow[b]{2}{*}{ Cultivar } & \multirow[b]{2}{*}{ Type } & \multicolumn{2}{|c|}{ Firmness $(\mathrm{lbf})^{\mathrm{z}}$} & \multicolumn{2}{|c|}{ SSC (\%) } & \multicolumn{2}{|c|}{ MA (\%) } & \multicolumn{2}{|c|}{ SSC:MA (ratio) } \\
\hline & & PR & TR & PR & TR & PR & TR & PR & TR \\
\hline Abundance ${ }^{y}$ & As & $3.0 \mathrm{abc}^{\mathrm{x}}$ & $2.1 \mathrm{abc}^{*}$ & $9.6 \mathrm{de}$ & $9.9 \mathrm{f}^{\star}$ & $1.3 \mathrm{~d}$ & $1.1 \mathrm{~d}^{*}$ & 7.2 & 8.8 \\
\hline Methley & As & $1.4 \mathrm{~d}$ & $0.7 c^{*}$ & $10.9 \mathrm{~b}$ & $10.4 \mathrm{e}^{*}$ & $1.3 \mathrm{~d}$ & $1.2 \mathrm{~cd}$ & 8.4 & 8.5 \\
\hline Obilnya & As & $4.2 \mathrm{a}$ & $2.5 \mathrm{ab}^{*}$ & $10.6 \mathrm{c}$ & $11.5 c^{*}$ & $2.1 \mathrm{a}$ & $2.1 \mathrm{a}$ & 5.1 & 5.6 \\
\hline Shiro & As & $2.6 \mathrm{bcd}$ & $1.6 \mathrm{bc}^{*}$ & $9.5 \mathrm{e}$ & $9.1 \mathrm{~h}^{*}$ & $1.6 \mathrm{~b}$ & $1.7 \mathrm{~b}$ & 5.9 & 5.4 \\
\hline Vanier & As & $3.9 \mathrm{ab}$ & $3.3 \mathrm{a}^{*}$ & $9.8 \mathrm{~d}$ & $10.7 \mathrm{~d}^{*}$ & $1.5 \mathrm{c}$ & $1.1 \mathrm{~d}^{*}$ & 6.4 & 9.6 \\
\hline \multicolumn{10}{|c|}{ ANOVA $P$ values for type III sums of squares } \\
\hline Cultivar (C) & & $<0.01$ & & $<0.01$ & & $<0.01$ & & & \\
\hline Maturity $(\mathrm{M})$ & & $<0.01$ & & $<0.01$ & & $<0.01$ & & & \\
\hline $\mathrm{C} \times \mathrm{M}$ & & 0.71 & & $<0.01$ & & $<0.01$ & & & \\
\hline
\end{tabular}

${ }^{\mathrm{z}} 1 \mathrm{lbf}=4.4482 \mathrm{~N}$

y'Abundance' was purchased from a nearby farm in Fairfield, ME, but other cultivars were grown at the research farm in Monmouth, ME.

${ }^{\mathrm{x}}$ Means separation within columns by Tukey's honestly significant difference. Means followed by the same letter are not significant.

*Indicates a significant effect of maturity stage within a cultivar.

$\mathrm{SSC}=$ soluble solids concentration; $\mathrm{MA}=$ malic acid.

Table 4. Fruit quality attributes of asian (As), american (Am), and european (E) plum cultivars harvested at the tree-ripe stage of maturity in 2016.

\begin{tabular}{llcccc}
\hline Cultivar & Type & ${\text { Firmness }(\mathbf{l b f})^{\mathrm{z}}}$ & SSC (\%) & MA (\%) & SSC:MA (ratio) \\
\hline Early Golden & As & - & $10.6 \mathrm{j}$ & $2.0 \mathrm{ab}$ & 5.3 \\
Methley & As & - & $11.7 \mathrm{i}$ & $1.4 \mathrm{e}$ & 8.7 \\
Obilnya & As & $2.2 \mathrm{c}^{\mathrm{y}}$ & $13.6 \mathrm{~h}$ & $1.9 \mathrm{bc}$ & 7.0 \\
Shiro & As & $0.9 \mathrm{~d}$ & $6.7 \mathrm{k}$ & $1.3 \mathrm{ef}$ & 5.1 \\
Kahinta & Am & $3.8 \mathrm{ab}$ & $14.8 \mathrm{~g}$ & $2.0 \mathrm{ab}$ & 7.3 \\
Superior & Am & $5.0 \mathrm{a}$ & $15.7 \mathrm{e}$ & $2.1 \mathrm{a}$ & 7.5 \\
Toka & Am & $1.8 \mathrm{~cd}$ & $19.8 \mathrm{~b}$ & $1.6 \mathrm{~d}$ & 12.3 \\
Caçak's Best & $\mathrm{E}$ & - & $15.3 \mathrm{f}$ & $1.0 \mathrm{~g}$ & 15.2 \\
Castleton & $\mathrm{E}$ & $5.0 \mathrm{a}$ & $17.3 \mathrm{~d}$ & $1.2 \mathrm{f}$ & 14.0 \\
Early Italian & $\mathrm{E}$ & - & $22.1 \mathrm{a}$ & $1.9 \mathrm{c}$ & 11.8 \\
Rosy Gage & $\mathrm{E}$ & $3.3 \mathrm{bc}$ & $19.5 \mathrm{c}$ & $1.7 \mathrm{~d}$ & 11.6 \\
Pvalue & & $<0.01$ & $<0.01$ & $<0.01$ & - \\
Type & & $1.6 \mathrm{~b}$ & $10.6 \mathrm{~b}$ & $1.6 \mathrm{ab}$ & 6.5 \\
$\quad$ Asian & & $3.5 \mathrm{a}$ & $16.8 \mathrm{a}$ & $1.9 \mathrm{a}$ & 9.0 \\
American & & $4.2 \mathrm{a}$ & $18.5 \mathrm{a}$ & $1.4 \mathrm{~b}$ & 18.2 \\
European & & $<0.01$ & $<0.01$ & - \\
\multicolumn{1}{c}{ Pvalue } & & & & & \\
\hline
\end{tabular}

${ }^{\mathrm{z}} 1 \mathrm{lbf}=4.4482 \mathrm{~N}$.

${ }^{y}$ Means separation within cultivar and within type by Tukey's honestly significant difference. Means followed by the same letter within cultivar or within type are not significant.

'Early Italian' was purchased from a supermarket in Orono, ME, the same day as testing. Other cultivars were grown at the research farm in Monmouth, ME.

SSC $=$ soluble solids concentration; $\mathrm{MA}=$ malic acid

The ratios of SSC to MA were greatest in european plums except for 'Toka' which had a ratio similar to european cultivars. The ratio of SSC to MA was lowest in 'Shiro' and 'Early Golden', and was highest in 'Caçak's Best'.

\section{Discussion}

Most of the cultivars in this study received consumer acceptance scores that were higher than Methley and Shiro, two cultivars that are grown in the northeastern United States and Canada for local marketing. These two cultivars scored 6.0 or below for overall liking, indicating that consumers neither liked nor disliked them or liked them slightly. The only other cultivar to score as low was Caçak's Best, which was included because of its unpleasant aftertaste that made it an example of an unacceptable cultivar. By contrast, 'Spring Satin' and 'Obilnya' scored above 7.0 , indicating that consumers liked them moderately to very much. Most of the european and american cultivars also scored near 7.0, indicating that consumers did not prefer one type more than another and that cultivar had a greater impact on overall liking than plum type.

In previous studies, hedonic scores for plums ranged from 3.3 to 7.8 depending on cultivar, quality, and stage of maturity (Crisosto et al., 2004; Meredith et al., 1992; Minas et al., 2013; Okie, 2005). The fruit tested in this study were harvested partially ripe and tree-ripe, which may be the reason for mean overall scores being 5.0 or above. Harvest at an earlier stage of maturity would likely have caused a greater disparity in consumer ratings. The difference in maturity between the two stages was relatively small, and in a few cases, MA was not significantly different between the two stages. The high scores for partially ripe fruit in most cultivars indicate that producers can harvest fruit before full ripeness to extend shelf life. A shelf test was not included in this study but could affect consumer acceptance.

Plum types differed in fruit quality attributes. American cultivars generally had greater SSC than asian cultivars and were likely rated higher than expected because of this. European plums also had higher SSC than asian plums, which has been previously reported (Sahamishirazi et al., 2017; Usenik et al., 2008). It is not 
clear why european plums received lower scores for color but could be due to the dark or dull appearance of the flesh.

Greater consumer acceptance has been associated with a greater SSC:MA (Crisosto et al., 2003; Guerra et al., 2010; Robertson et al., 1992; Usenik et al., 2014). However, this did not occur in our study in which SSC:MA was 14.0 in 'Castleton' and 4.2 in 'Early Golden', both of which received similar acceptability scores. 'Caçak's Best' had the highest SSC:MA ratio but scored lower because of its aftertaste. In plums, previous research indicates that SSC:MA can vary from 5.4 to 20.8 among many different cultivars (Lozano et al., 2009; Robertson et al., 1992; Usenik et al., 2008) and from 13.2 to 37.5 in 'Black Amber' harvested at several stages of maturity (Crisosto et al., 2004), a range two to four times as large as what occurred in our study. The lower SSC:MA in our study could also be due to higher MA, a possible effect of the cool growing conditions of Maine compared with regions that are warmer, such as California (Crisosto et al., 2004) and Spain (Díaz-Mula et al., 2009). In addition, it is possible that flavor and aroma in these cultivars were more developed than in fruit that have undergone more substantial transport or storage periods, and this may have influenced consumer liking to a greater extent than SSC:TA.

Texture is an important determinant in consumer acceptance but is typically indirectly measured as firmness. Plums are considered too soft when firmness decreases to below 1 lbf (Robertson et al., 1992). This was apparent in the case of 'Methley' and 'Shiro', which received the lowest ratings for texture and had tree-ripe firmness below $1 \mathrm{lbf}$. It was not clear if consumers had an upper limit for firmness preference because 'Obilnya' and 'Kahinta' received high scores for texture despite having firmness above 3 lbf. However, flesh firmness at optimum maturity varies with cultivar, which prevents the use of one standard for every cultivar (Crisosto, 1994). This was the case in this study in which flesh firmness varied by cultivar from 1.4 to $4.2 \mathrm{lbf}$ at the partially ripe stage and $0.7-3.3 \mathrm{lbf}$ in tree-ripe fruit. The same standard could not be used for every cultivar because Shiro would have been underripe and Obilnya would have been overripe if each had been harvested according to one standard firmness value. The low texture scores for 'Toka' were possibly because of mealy texture and peel thickness. However, these traits were not directly measured by the untrained consumer panel.

Additional qualities such as bitterness, astringency, off-flavors, and aroma also play an important role in consumer acceptance (Crisosto et al., 2006; Guerra et al., 2010; Robertson et al., 1992; Usenik et al., 2014) but were not measured because of the constraints of an untrained consumer testing population. Astringency of the skin was not included in the sensory questioning but may have been a factor in consumer acceptance of some of the cultivars, particularly Vanier, and may have been a factor in consumer rating of skin tartness. Aroma may be important to consumer acceptance, particularly with cultivars such as Early Golden and Toka. Plums are not considered to be highly aromatic (Gómez and Ledbetter, 1994), but this may be because of the harvest and storage practices that lengthen shelf life. The greater development of flavor and aroma in these cultivars that resulted from harvest at advanced maturity and testing soon after harvest was likely an important factor contributing to consumer acceptance. For markets that do not require harvest at an early stage of maturity, selection of cultivars with more complex flavors may enhance consumer acceptance and increase plum consumption.

American and european plums are relatively unknown to growers and consumers but have greater cold temperature tolerance than asian plums and would allow growers in colder regions to produce locally grown plums. As selection of fruit cultivars becomes based on consumer acceptance, Shiro and Methley may become less important in plum production in colder regions, although plums are currently a minor fruit crop in northeast United States and Canada. Expansion of the local market may be possible by growing cultivars such as Obilnya, Abundance, Spring Satin, Toka, Superior, Kahinta, Rosy Gage, and Castleton, as well as other cultivars not tested in this study.

\section{Literature cited}

Abdi, N., P. Holford, and W.B. McGlasson. 1997. Effects of harvest maturity on the storage life of japanese plums. Austral. J. Expt. Agr. 37:391-397.

Bae, H., S.K. Yun, J.H. Jun, I.K. Yoon, E.Y. Nam, and J.H. Kwon. 2014. Assessment of organic acid and sugar composition in apricot, plumcot, plum and peach during fruit development. J. Appl. Bot. Food Qual. 87:24-29.

Boyhan, G.E., J.D. Norton, M.H. Hollingsworth, J.A. Pitts, J.B. Witt, H.W. Ivey, and J.T. Owen. 1996. Plum variety trials in Alabama 1986-1995. Alabama Agr. Expt. Sta. Bul. 628.

Candan, A.P., J. Graell, and C. Larrigaudière. 2008. Roles of climacteric ethylene in the development of chilling injury in plums. Postharvest Biol. Technol. 47:107-112.

Chauvin, M.A., M. Whiting, and C.F. Ross. 2009. The influence of harvest time on sensory properties and consumer acceptance of sweet cherries. HortTechnology 19:748-754.

Cooley, D., W. Autio, D. Greene, J. Clements, M. Conklin, T. Bradshaw, H. Faubert, G. Koehler, R. Moran, and G. Hamilton. 2015. 2015 New England tree fruit management guide. Cornell Univ., Ithaca, NY.

Corollaro, M.L., F. Gasperi, and L.C. Grappadelli. 2014. An overview of sensory quality of apple fruit. J. Amer. Pomol. Soc. 68:141-157.

Crisosto, C.H. 1994. Stone fruit maturity indices: A descriptive review. Postharvest News Info. 5(6):65-68.

Crisosto, C.H., G.M. Crisosto, and E. Bowerman. 2003. Understanding consumer acceptance of peach, nectarine and plum cultivars. Acta Hort. 604: 115-119.

Crisosto, C.H., D. Garner, G.M. Crisosto, and E. Bowerman. 2004. Increasing 'Blackamber' plum (Prunus salicina Lindell) consumer acceptance. Postharvest Biol. Technol. 34:237-244.

Crisosto, C.H., G.M. Crisosto, and F. Neri. 2006. Understanding tree fruit quality based on consumer acceptance. Acta Hort. 712:183-190.

Díaz-Mula, H.M., P.J. Zapata, F. Guillén, D. Martínez-Romero, S. Castillo, M. Serrano, and D. Valero. 2009. Changes in hydrophilic and lipophilic antioxidant activity and related bioactive compounds during postharvest storage of yellow and purple plum cultivars. Postharvest Biol. Technol. 51:354-363. 
Fajt, N. and V. Usenik. 2010. Plum cultivar testing in the western part of Slovenia. 2010. Acta Hort. 874:275-280.

Gilbert, J.L., J. Olmstead, T. Coluquhoun, L. Levin, D. Clark, and H. Moskowitz. 2014. Consumer-assisted selection of blueberry fruit quality traits. HortScience 49:864-873.

Gómez, E. and C. Ledbetter. 1994. Comparative study of the aromatic profiles of two different plum species: Prunus salicina Lindl. and Punus simonii L. J. Sci. Food Agr. 65:111-115.

Guerra, M., M.A. Sanz, and P.A. Casquero. 2010. Influence of harvest dates on quality, storage capacity and sensory attributes of european plum cv. Green Gage. Food Sci. Technol. Intl. 15:527-534.

Hansen, H.E. 1915. Progress in plant breeding. South Dakota Agr. Expt. Sta. Bul. 159.

Kader, A. and F.G. Mitchell. 1989. Maturity and quality, p. 191-196. In: J. LaRue and R.S. Johnson (eds.). Peaches, plums and nectarines: Growing and handling for fresh market, Univ. California Publ. 3331.

Lozano, M., M. Carmen, M. VidalAragoìn, M.C. Ayuso, M.J. Bernalte, J. Garciì, and B. Velardo. 2009. Physicochemical and nutritional properties and volatile constituents of six japanese plum (Prunus salicina Lindl.) cultivars. Eur. Food Res. Technol. 228:403-410.
Meredith, F.I., S.D. Senter, W.R. Forbus, Jr., and J.A. Robertson. 1992. Postharvest quality and sensory attributes of 'Byrongold' and 'Rubysweet' plums. J. Food Qual. 15:199-209.

Minas, I.S., G.M. Crisosto, D. Holcroft, M. Vasilakakis, and C.H. Crisosto. 2013. Postharvest handling of plums (Prunus salicina Lindl.) at $10^{\circ} \mathrm{C}$ to save energy and preserve fruit quality using an innovative application system of 1-MCP. Postharvest Biol. Technol. 76:1-9.

Norton, J.D., T.L. Kamps, and T.E. Conaty. 1987. New plums for the south. Proc. 7th Annu. Mtg. Shortcourse. Alabama Fruit Veg. Growers Assn., Auburn, AL. p. 65-78.

Okie, W.R. and D.W. Ramming. 1999. Plum breeding worldwide. HortTechnology 9:162-176.

Okie, W.R. 2005. 'Spring Satin' plumcot. J. Amer. Pomol. Soc. 59:119-124.

Olmstead, M.A., J.L. Gilbert, T.A. Coluquhoun, D.G. Clark, R. Kluson, and H.R. Moskowitz. 2015. In pursuit of the perfect peach: Consumer-assisted selection of peach fruit traits. HortScience 50:1202-1212.

Peryam, D.R. and F.J. Pilgrim. 1957. Hedonic scale method of measuring food preferences. Food Technol. 11:10-14.

Robertson, J.A., F.I. Meredith, S.D. Senter, W.R. Okie, and J.D. Norton.
1992. Physical, chemical and sensory characteristics of japanese-type plums grown in Georgia and Alabama. J. Sci. Food Agr. 60:339-347.

Sahamishirazi, S., J. Moehring, W. Claupein, and S. Graeff-Hoenninger. 2017. Quality assessment of 178 cultivars regarding phenolic, anthocyanin and sugar content. Food Chem. 214:694-701.

Singh, S.P. and Z. Singh. 2008. Postharvest oxidative behavior of 1-methylcyclopropene treated japanese plums (Prunus salicina Lindell) during storage under controlled and modified atmospheres. Postharvest Biol. Technol. 74:26-35.

Stone, H., R. Bleibaum, and H.A. Thomas. 2012. Sensory evaluation practices. 4th ed. Elsevier, Waageningen, The Netherlands.

U.S. Department of Agriculture. 2017. Food availability. 1 Feb. 2017. <https:// www.ers.usda.gov/data-products/foodavailability-per-capita-data-system/foodavailability-documentation $/>$.

Usenik, V., D. Kastelec, R. Veberič, and F. Stampar. 2008. Quality changes during ripening of plums (Prunus domestica L.). Food Chem. 111:830-836.

Usenik, V., F. Štampar, and D. Kasteleč. 2014. Indicators of plum maturity: When do plums become tasty? Scientia Hort. 167:127-134. 